\title{
TUBERCULOSIS AND HUMAN IMMUNODEFICIENCY VIRUS CO-INFECTION: CLINICO-DEMOGRAPHIC DETERMINANTS AT AN ANTI-RETROVIRAL THERAPY CENTER IN NORTHERN INDIA.
}

Giri Om Prakash, Giri Vishal Prakash, Vishwakarma Kirti, Datta Debranjan

\begin{abstract}
\section{Background:}

In India, Tuberculosis (TB) is endemic and Human immunodeficiency virus (HIV) infection is epidemic in few states. The risk of developing TB in people living with HIV (PLHIV) is about 19 (27-22) times greater than those without it. TB is major cause of death in HIV-TB co-infected patients. Globally 0.4 million deaths occur annually due to HIV-TB disease.
\end{abstract}

\section{Material \& Methods:}

The present observational study was conducted at Darbhanga Medical College and Hospital ART (Antiretroviral therapy) center during period from January to June 2017. Data of HIV-TB co-infected patients was collected from HIV-TB register and entered into Microsoft Excel sheet for analysis using Statistical Package for the Social Sciences.

\section{Results:}

Young persons mostly from the labouring class working in other states were most affected. Pulmonary tuberculosis (sputum smear positive) was most common co-infection. Baseline CD4 cell count at the time of presentation was observed to be low (less than 200 cells/ $\mu \mathrm{L}$ ) in 46.64\% HIV-TB co-infected patients.

\section{Conclusion}

Rural young people working as migrant labourer need focus of health interventions. They should be educated and screened for HIV and TB. Baseline CD4 cell count should be done in all PLHIV cases to assess their immune status.

Keywords: Tuberculosis; HIV infection; CD4 Lymphocyte Count; Treatment Outcome

\section{Correspondence:}

Dr. Vishal Prakash Giri,

Assistant Prof. Department of Pharmacology, Shri Ram

Murti Smarak Institute ofMedical Sciences, Bareilly,

243202, India

Email: drypgiri@gmail.com 


\section{INTRODUCTION}

Thirty seven percent of HIV infected patients who initiate ARV (antiretroviral) have advanced HIV infection (CD4 count $<200$ cells $/ \mu \mathrm{L}$ ). These patients are at high risk of death. With advent of newer antiretroviral that have greater effectiveness, improved tolerability and fewer adverse effects, survival of these patients have been prolonged and hence HIV infection has evolved from a probable death sentence to a chronic disease. ${ }^{[1,2]} \mathrm{HIV}$ infection is an important cause of death among adults. Hence it is a matter of major health concern. HIV evade and invade innate immune system. ${ }^{[3]}$

First-line antiretrovirals recommended by World health Organisation (WHO) for the treatment of HIV infection are Tenofovir disoproxil fumarate (TDF) and Lamivudine (3TC) or Emitricitabine (FTC) and either the nonnucleoside Efavirenz (EFV) or the intergrase inhibitor Dolutegravir (DTG). The secondline treatment recommendation is two nucleos(t)ide analogues and a boosted protease inhibitor either Lopinavir/ Ritonavir (LPV/R) or Dorunavir/ Ritonavir (DRV/R). ${ }^{[4]}$

Human immune system consists of ancient innate immune system and acquired adaptive immune system. The principal functions of immune system are recognition and elimination of foreign antigens. In addition, it is also responsible for formation of immunological memory and development of tolerance to self antigens. T-lymphocytes mediate cellular immunity and B-lymphocytes mediate humoral immunity. These provide adaptive immunity and work in close collaboration with innate immune system.

$\mathrm{CD} 4+\mathrm{T}$ cells are part of adaptive immune system. These are crucial in for regulated and effective immune response to pathogens. Their proper functioning is vital for survival of human beings. They play a major role in mediating immune response through secretion of specific cytokines. They are also responsible for activation of cells of the innate immune system, B-lymphocytes, cytotoxic cells as well as suppression of immune reaction. ${ }^{[5]}$

HIV causes immunosuppressant that leads to diseases caused by opportunistic pathogens in HIV infected persons. These opportunistic infections (Ols) include Pneumocytic pneumonia, Toxoplasma gonadi encephalitis, cryptosporidiosis, microsporidisis, Mycobacterium tuberculosis infection and disease, Mycobacterium avium complex (MAC) disease, bacterial respiratory disease, bacterial enteric disease, bartonellosis, syphilis, candidiasis, mycoses ,aspergillosis, cytomegalovirus disease, non-cytomegalo virus herpes, JC virus infection, hepatitis B \& C infection, and miscellaneous diseases (malaria, leishmaniasis, cryptopsoriasis, penicillosis marneffei, chagas disease). Ols adversely accelerate HIV progression and increase transmission of HIV . ${ }^{[6]}$

The role of CD4 cell count testing in people living with HIV (PLHIV) is changing with a shift away from using it to decide when to start treatment (ART) and how to monitor treatment. ART can be started irrespective of CD4 cell count and CD4 cell count monitoring can be stopped in PLHIV who are stable on ART as ART efficiency can be monitored by viral load. At present, CD4 cell count testing is an important tool in the management of advanced HIV disease. Cryptococcal antigen ( $\mathrm{CrAg}$ ) and urine lateral flowLAM assay for TB diagnosis are recommended for all patients with a CD4 cell count less than 100 cells/ $\mu \mathrm{L},{ }^{7-99} T$ The present study was designed with the aims to evaluate demographic profile and baseline CD4 cell count in the patients of HIV co-infected with pulmonary and extra-pulmonary tuberculosis.

\section{MATERIAL AND METHODS}

The present cross-sectional, observational study was undertaken with objectives of finding out demographic profile, CD4 cell count, type of TB and treatment outcome of HIV-TB co-infected patients who attended ART center, Darbhanga Medical College and Hospital during the period from $1^{\text {st }}$ January 2017 to $30^{\text {th }}$ June 2017. The data from HIV-TB register were entered in the computer and analyzed statistically.

The HIV serological testing was done as per National AIDS Control Organization (NACO) guidelines. HIV seropositivity was diagnosed by CombAids- RS kit, Meriscreen HIV 1-2 WB kit and Trispot kit supplied by NACO to integrated counseling and testing centre (ICTC), Darbhanga. Cy Flow counter was used for CD4 cell count [Figure 1].

Pulmonary tuberculosis (Tuberculosis of lung parenchyma and tracheobronchial tree) was

Diagnosed when either sputum smear was positive by fluorescent microscopy or when clinical features and/ or radiological imaging (x-ray chest/ CT scan chest) were suggestive of pulmonary tuberculosis. Extra-pulmonary tuberculosis (tuberculosis of organs other than lung parenchyma or tracheobronchial tree) was diagnosed by culture of FNACl biopsy specimen on solid media (LJ media) or histopathological examination (epitheloid granuloma with caseous material) or radiological imaging or clinical judgement.

The statistical analysis was done using Statistical Package for the Social Sciences (SPSS) (Version 20.0. Armonk, NY: IBM Corp.). Descriptive statistics and chi-square tests were performed. 


\section{RESULTS}

A total 508 (five hundred eight) HIV-TB co-infected patients were studied. 278 (54.72\%) were observed to be in the age group of 35-59 years, out of which $150(29.52 \%), 19(3.74 \%)$ and 109 (21.45\%) were HIV-PTB smear positive, HIV-TB smear negative and HIV-EPTB respectively. Next age group maximally affected was 15-34 years $203(39.96 \%)$ followed by less than 14 years 17 (3.34\%). Patients of age group 60 and above were least affected 10 $(1.96 \%)$. Gender distribution of all patients revealed $339(66.73 \%)$ males and $169(33.27 \%)$ females. Thus males outnumbered females. The mean \pm SD age of HIV-TB co-infected patient was observed to be $32 \pm 11.7$ years [Table 1].

Two hundred fifty six (50.39\%) patients had CD4 cell count less than $200 \mathrm{cells} / \mu \mathrm{L}$. Out of which 149 (29.33 \%) had HIV-TB smear positive status.
14 (2.75\%) were HIV-TB smear negative and 93 (18.31\%) suffered from HIV-EPTB 2. Relation to CD4 count less than 200per cells/ $\mu \mathrm{L}$ with pulmonary and extra-pulmonary TB was calculated using ANOVA and it was found to be insignificant $(F=0.31$, $p=0.74)$. Yates corrected degrees of freedom were used for interpretation of the result. 252 (49.60\%) patients had CD4 cell count more than $200 \mathrm{cells} / \mu \mathrm{L}$. The mean CD4 cell count observed amongst HIVPTB smear positive, HIV-PTB smear negative and HIV-EPTB patients was 227.6, 270.15 and 228.58 respectively. Relation to CD4 count more than 200 cells/ $\mu \mathrm{L}$ with pulmonary and extra-pulmonary TB was also not significant $(F=0.45, p=0.64)$. [Table 2]. Mortality was recorded 25 (4.92\%) cases, out of which maximum 17 (3.34\%) had HIV-TB coinfected with smear positive pulmonary tuberculosis (PTB) and 8 (1.57\%) had EPTB [Table 3].

Table 1: Characteristics of patients with HIV-TB co-infection

\begin{tabular}{|c|c|c|c|c|}
\hline $\begin{array}{l}\text { Age group } \\
\text { (in years) }\end{array}$ & $\begin{array}{l}\text { Total number } \\
\text { of patients } \\
(n=508)\end{array}$ & $\begin{array}{c}\text { Pulmonary } \\
\text { TB sputum } \\
\text { smear }(+) \\
(n=278)\end{array}$ & $\begin{array}{c}\text { Pulmonary TB } \\
\text { sputum smear } \\
(-) \\
(n=42)\end{array}$ & $\begin{array}{c}\text { Extra } \\
\text { Pulmonary } \\
\text { TB } \\
(n=188)\end{array}$ \\
\hline$\leq 14$ & 17 & 13 & 1 & 3 \\
\hline $15-34$ & 203 & 108 & 21 & 74 \\
\hline $35-59$ & 278 & 150 & 19 & 109 \\
\hline 60 and above & 10 & 7 & 1 & 2 \\
\hline \multicolumn{5}{|l|}{ Gender } \\
\hline Male & 339 & 191 & 27 & 121 \\
\hline Female & 169 & 87 & 15 & 67 \\
\hline
\end{tabular}

Statistic is 2.0928. The $p$-value is 0.553371 . The result is not significant at $p<0.05$.

There was no correlation between age group and type of tuberculosis (pulmonary and extra-pulmonary). The chi-square statistic is 4.5787 . The $p$-value is 0.205377 . The result is not significant at $p<0.05$

Table 2: CD4 count in relation to pulmonary and extra-pulmonary tuberculosis.

\begin{tabular}{|c|c|c|c|c|c|}
\hline 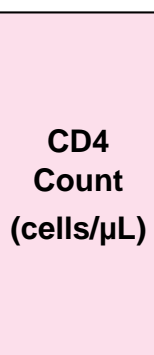 & $\begin{array}{l}\text { Pulmonary } \\
\text { TB sputum } \\
\text { smear (+) } \\
\text { Mean士SD } \\
\text { (n) }\end{array}$ & $\begin{array}{l}\text { Pulmonary } \\
\text { TB sputum } \\
\text { smear (-) } \\
\text { Mean } \pm \text { SD } \\
\text { (n) }\end{array}$ & $\begin{array}{c}\text { Relation to } \\
\text { CD4 count with } \\
\text { Pulmonary TB } \\
\text { Sputum smear (+) } \\
\text { and sputum smear } \\
(-) \\
\text { Significance } \\
\text { (p-value) }\end{array}$ & $\begin{array}{c}\text { Extra } \\
\text {-Pulmonary } \\
\text { TB } \\
\text { Mean } \pm \text { SD } \\
\text { (n) }\end{array}$ & $\begin{array}{c}\text { Relation of } \\
\text { CD4 count with } \\
\text { pulmonary } \\
\text { TB and extra- } \\
\text { pulmonary TB } \\
\text { Significance } \\
\text { ( } p \text {-value) }\end{array}$ \\
\hline$\leq 200$ & $\begin{array}{c}111.83 \pm 49.57 \\
(149)\end{array}$ & $\begin{array}{c}118.46 \pm 58.16 \\
(14)\end{array}$ & 0.64 & $\begin{array}{c}116.45 \pm 49.26 \\
(93)\end{array}$ & 0.74 \\
\hline$>200$ & $\begin{array}{c}356.35 \pm 147.86 \\
(129)\end{array}$ & $\begin{array}{c}346 \pm 140.23 \\
(28)\end{array}$ & 0.73 & $\begin{array}{c}339.34 \pm 109.89 \\
(95)\end{array}$ & 0.64 \\
\hline $\begin{array}{l}\text { Mean CD4 } \\
\text { count }\end{array}$ & $\begin{array}{l}227.6 \\
(278)\end{array}$ & $\begin{array}{c}270.15 \\
(42)\end{array}$ & & $\begin{array}{c}228.54 \\
(188)\end{array}$ & \\
\hline
\end{tabular}


Correlation is significant at the 0.05 level. $\quad n=N u m b e r$ of patients, SD= Standard deviation.

Relation of CD4 count $<200$, with pulmonary TB sputum smear (+) and sputum smear (-) reveals $95 \% \mathrm{Cl}$ -21.147 to 34.3070 , t-statistic: 0.471 , DF 161. Relation of CD cell count $>200$, with pulmonary TB sputum smear (+) and pulmonary sputum smear (-) reveals $95 \% \mathrm{Cl}-70.7090$ to 50.0090, t- statistic: - 0.339, DF 15.

Table 3: Treatment outcome of the patients with HIV-TB co-infection

\begin{tabular}{|l|l|l|l|}
\hline \multicolumn{1}{|c|}{$\begin{array}{c}\text { Treatment } \\
\text { Outcomes }\end{array}$} & $\begin{array}{c}\text { Pulmonary TB } \\
\text { Sputum smear } \\
(\mathbf{+}) \\
(\mathbf{n = 2 7 8 )}\end{array}$ & $\begin{array}{c}\text { Pulmonary. TB } \\
\text { sputum smear (-) } \\
(\mathbf{n = 4 2 )}\end{array}$ & $\begin{array}{c}\text { Extra-Pulmonary } \\
\text { TB } \\
(\mathbf{n = 1 8 8})\end{array}$ \\
\hline Treated & 27 & 1 & 12 \\
\hline Ongoing/ Follow up & 172 & 39 & 164 \\
\hline Defaulter & 1 & 1 & 1 \\
\hline Transferred/LAMA & 61 & 1 & 3 \\
\hline Death & 17 & 0 & 8 \\
\hline
\end{tabular}

$\mathrm{n}=$ number of patients.

Complete cure was observed more among HIV pulmonary TB sputum smear $(+)$ patients than HIV pulmonary TB sputum smear (-) patients. Found statistically significant $(p$ value $<0.05)$.

Follow up was major treatment outcome among HIV pulmonary TB sputum smear $(+)$ patients and HIV pulmonary TB sputum smear (-) patients. Statistically significant $(p<0.05)$.

Death occurred more among HIV pulmonary TB patients than HIV extra -pulmonary TB patients. Found statistically significant ( $p$ value $<0.05$ ).

\section{DISCUSSION}

The present study revealed that males are more susceptible to HIV-TB co-infection than females by acquiring $66.73 \%$ of total figure. The reasons being that men of our state bear the disappropriate burden of poverty and migrate to other developed states of India in search of job (e.g. driver, hotel worker and guards etc), live alone and return home after 6-12 months after earning money for the family. This is supported by studies conducted by Dahiya et al and Chandwani et al. The present study finding not in accordance with Chandra et al, Aturaka et, Said et al and Olowe et al, who reported susceptibility of females in $55.62 \%, 58.60 \%, 72.30 \%$ and $54.40 \%$ of HIV-TB co-infected patients. ${ }^{[10-14,17]}$

According to the age wise distribution, $40.75 \%$ of the individuals belonged to the age group of 35-59 years. Similar to the finding reported by Chandwani et al (35.61\%), Aturaka et al (47.6\%), Said et al (43\%) and Kavya et al (54\%). ${ }^{[1,13,14,15]}$

Dahiya et al reported 25-34 age group to be maximally $(60.60 \%)$ affected by HIV-TB co-infection. ${ }^{[10]}$

The mean age of the present study population was found to be 32 years, which is comparable to the findings made by Dahiya et al (31.18 years) and Chandra et al (36.67 years). ${ }^{[10,12]}$
In this study pulmonary tuberculosis was predominantly (66.99\%) found in HIV-TB infected cases. This is consistent with findings reported by Chandra et al (60.58\%), Kamath et al (60.20\%) and Olowe et al (94.30\%) ${ }^{[12,16,17]}$ but contrasting results have been found in studies conducted by Dahiya et al, Chandra et al and Kavya et al ${ }^{[10,12,15]}$ with higher incidence of extra-pulmonary TB than pulmonary TB among HIV-TB co-infected patients.

A higher percentage of patients with HIV-PTB $(32.38 \%)$ were observed to have CD4 cell count less than 200 cells $/ \mu \mathrm{L}$ as compared to HIV- EPTB (30.90\%). This is not consistent with the reports of Chandwani et al and Kavya et al who observed CD4 cell count less than 200 cells $/ \mu \mathrm{L}$ in higher number of patients with EPTB cases, the figures being $58.16 \%$ and $61.25 \%$ respectively. ${ }^{[11,15]}$

Maximum number of cases (50.39\%) had CD4 cell count less than 200 cells $/ \mu \mathrm{L}$. Our study results correlates with Chandwani et al, Yasmin et al and Sidheshwari et al study reports of $59.17 \%, 60.38 \%$ and $60 \%$ respectively. ${ }^{[1,18,19]}$ This figure points out that with decrease in CD4 cell count there is increased chance of TB in HIV- infected patients.

Mean CD4 cell count in HIV-TB patients noted in the present study is 227.6. This observation is in accordance with observations made by Dahiya et 
al (199.0), Chandra et al (218.32), Kamath et al (147.47), Rajbhandari et al (123.70) and Singh PK $(166.7) \cdot{ }^{[10,12,16,20,21]}$

Out of total 320 PTB cases in our study $278(54.72 \%)$ had sputum smear positive PTB and 42 (8.27\%) sputum smear negative PTB. 149 (26.33\%) smear positive cases and $14(2.75 \%)$ smear negative cases have been noted in the present study to have CD4 cell count less than 200 cells/ $\mu$ L. 93(18.36\%) EPTB cases had CD4cellcount less than 200 cells $/ \mu \mathrm{L}$. Thus in our study advanced HIV infection was noted in higher percentage of sputum smear positive PTB cases followed by EPTB and least in sputum smear negative cases.

Jyostna et al observed that higher number of patients who had CD4 cell count less than 200 cells/ $\mu \mathrm{L}$ had EPTB followed by smear negative PTB and least in sputum positive PTB.

We observed mortality of 25 (4.92\%) HIV-TB coinfected patients, out of which $17(3.35 \%)$ had HIV co-infected sputum smear positive PTB and 8 (1.57\%) EPTB.

Large proportion of HIV-TB co-infected patients die in hospital due to invasive bacterial infections as these patients are at high risk of nosocomial infections due to immunosuppressant, frequent invasive procedures and multispectral

\section{CONCLUSION}

HIV infection is the most potent risk factor for tuberculosis and HIV-TB co-infection is a serious public health concern. The independent risk factors for unfavorable outcome found in this study were low baseline CD4 cell count (less than 200 cells $/ \mu \mathrm{L}$ ), rural background of the patients, young age and sputum smear positive pulmonary tuberculosis. Based on these finding we recommend that stakeholders involved in HIV and TB management should focus on these risk factors. Grass-root awareness among the rural population and working class about the disease may be the key in prevention and early detection the disease.

\section{ACKNOWLEDGEME NT}

Authors are thankful to staff of ART center, Darbhanga Medical College and Hospital, Darbhanga for their co-operation throughout the study.

Ethical clearance: Approved by IEC.

Conflict of Interest: NIL.

Source of Funding: NIL.

\section{REFERENCES}

1. Trickey A, May MT, Vehreschild JJ, Obel N, Gill MJ, Crane HM, Boesecke C, et al., Antiretroviral
Therapy Cohort Collaboration. Survival of HIVpositive patients starting antiretroviral therapy between 1996 and 2013: a collaborative analysis of cohort studies. The Lancet HIV 2017;4:349-356.

2. Ford N, Doherty M. The Enduring Challenge of Advanced HIV Infection. N Engl J Med 2017; 377:283-284.

3. Alqudah MA, Yaseen MM, Yaseen MM. HIV-1 strategies to overcome the immune system by evading and invading innate immune system. HIV \& AIDS Review 2016;15:1-12.

4. Vitoria $M$, Ford $N$, Clayden $P$, Pozniak AL, Hill AM. When could new antiretrovirals be recommended for national treatment programmes in low-income and middle-income countries: results of a WHO Think Tank. Curr Opin HIV AIDS 2017;12:414-422.

5. Luckheeram RV, Zhou R, Verma $A D$, Xia B. CD4+T cells: differentiation and functions. Clin Dev Immunol 2012; 925135. doi:10.1155/1012/925135.

6. Guidelines for prevention and treatment of opportunistic infections in HIV infected adults and adolescents. http://aidsinfo.nih.gov/ guidelines [updated October 22, 2015].

7. Ford N, Meintjes G, Vitoria M, Greene $G$, Chiller $T$. The evolving role of CD4 cell counts in HIV care. Current Opinion HIV AIDS 2017;12:123-128.

8. World Health Organization. Consolidated guidelines on the use of antiretroviral drugs for treating and preventing HIV infection: recommendations for a public health approach. World Health Organization; 2016.

9. Bouteloup V, Sabin C, Mocroft A, et al. Reference curves for CD4 T-cell count response to combination antiretroviral therapy in HIV-1-infected treatment-naive patients. HIV Med 2017; 18:33-44.

10. Dahiya N, Bachani D, Das R, Rasania SK. Socio-demographic and clinical profile of HIV positive patients attending integrated counseling and testing centre of a primary health centre in Delhi. SAARC J Tuber Lung Dis HIVIAIDS 2017;15:22-26.

11. Chandwani J, Soni P, Parihar G, Meena C. Evaluation of CD4 Cell Count and its Associating Factors-In HIV-TB Co-Infection. Int. J. Curr. Microbiol. App. Sci 2017;6:747-752.

12. Chandra NM, Babu RA, Prasad DTS, Devulapalli M, Banu SSK, Avanthi B, et al. Epidemiological surveillance of tuberculosis among HIVIAIDS seropositive individuals 
attending ART center at a tertiary care teaching hospital. Int J Community Med Public Health 2017;4:2816-2824.

13. Aturaka SO, Abiodun O, Omotola O, Adebimpe WO, Philip Imohi et al.. Prevalence and Correlates of TB and HIV Co-infection Among People Living with HIVIAIDs at the DLHM Hospital, Calabar. American Journal of Health Research 2017;5:106-109.

14. Said K, Verver S, Kalingonji A, Lwilla F, Mkopi A, Charalambous S, Reither K. Tuberculosis among HIV-infected population: incidence and risk factors in rural Tanzania. Afri Health Sci 2017;17: 208-214.

15. Kavya S, Anuradha K, Venkatesha D. CD4 count evaluation in HIV -TB co-infection before and after antitubercular treatment. Int J Res Med Sci 2014; 2: 1031- 1034.

16. Kamath $R$, Sharma $V$, Pattanshetty $S$, Hegde MB, Chandrasekaran V. HIV-TB coinfection: Clinico-epidemiological determinants at an antiretroviral therapy center in Southern India. Lung India: official organ of Indian Chest Society 2013;30:302-306.

17. Olowe $\mathrm{OA}$, Makanjuola OB, Adekami AS, Adefioye OJ. Epidemiological characteristics and clinical outcome in a population of TB patients in South -Western
Nigeria. European Journal of microbiology and immunity 2017; 2: 127-132.

18. Yasmin T, Nandan K. Correlation of Pulmonary Tuberculosis in HIV Positive Patients and its Association with CD4 Count. Int. J. Life. Sci. Scienti. Res 2016;2:733-736.

19. Siddeswari R, Amaravathi KS, Rao NS, Rewari B, Kumar P. HIVIAIDS-tuberculosis (pulmonary and extra pulmonary) co-infection: CD4 correlation. International Journal of Research in Medical Sciences 2016;28:1035-1039.

20. Rajbhandari $P$, Bhattacharya SK, Gurung R, Poudyal N, Pradhan B. CD4 T Cell Count in Newly diagnosed PTB Patients With Reference to their HIV Sero status. Medical Journal of Shree Birendra Hospital 2017;15:32-39.

21. Singh RK. Prevalence of HIV/TB Co-infection among HIV Patients: Hospital Based Study from Northern Part of India. The Journal of the Association of Physicians of India 2017;65:106.

22. Escada RO, Velasque L, Ribeiro SR, Cardoso SW, Marins LM, Grinsztejn E, Lourenço MC, Grinsztejn B, Veloso VG. Mortality in patients with HIV-1 and tuberculosis co-infection in Rio de Janeiro, Brazil-associated factors and causes of death. BMC infectious diseases 2017 May 30;17:373-383. 